Crameri, K. (2015) Political power and civil counterpower: the complex dynamics of the Catalan independence movement. Nationalism and Ethnic Politics, 21(1). pp. 104-120.

Copyright @ 2015 Taylor \& Francis, LLC

A copy can be downloaded for personal non-commercial research or study, without prior permission or charge

Content must not be changed in any way or reproduced in any format or medium without the formal permission of the copyright holder(s)

When referring to this work, full bibliographic details must be given

http://eprints.gla.ac.uk/101014

Deposited on: 16 March 2015

Enlighten - Research publications by members of the University of Glasgow http://eprints.gla.ac.uk 


\title{
Political Power and Civil Counterpower: The Complex Dynamics of the Catalan Independence Movement
}

\begin{abstract}
Civil pro-independence associations are playing an increasingly significant role in Catalonia's independence movement, putting pressure on the Catalan government to work decisively towards independence. This has led many Catalans to characterize the movement as a "bottom-up" phenomenon. This contribution analyses the shifting power dynamics within mainstream Catalan nationalism over the last decade, challenging simplistic notions of "top-down" and "bottom-up" pressures for change. In fact, the movement is now inherently multidimensional - partly thanks to the pivotal role of the cultural elites and their grasp of the power of new media - and this in itself accounts in large part for its success.
\end{abstract}

Catalan nationalism has historically concerned itself with Catalonia's place within Spain, but this stateless nation has recently seen a momentous shift towards mass support for independence. This has now gone so far as to become what Viva Ona Bartkus would define as a "secession crisis", meaning that support for secession is widespread enough to have forced the Spanish government to react to Catalan demands - if only by a determined refusal to grant them any legitimacy. ${ }^{1}$ The reasons for this sudden crisis are complex and it is not my intention to address them here. ${ }^{2}$ Instead, the focus of this contribution is on the remarkable role now being played by civil groups in the independence movement.

Civil associations have been the principal protagonists at key moments in the evolution of Catalonia's recent progress towards majority support for secession. For example, on 10 July 2010, a million people participated in a demonstration in Barcelona in support of Catalonia's new Statute of Autonomy, which had been the subject of an unfavorable ruling by Spain's Constitutional Court. On 11 September 2012 (Catalonia's national day), that figure was beaten by a march - this time for independence - that is estimated to have drawn 1.5 million. $\underline{3}$ Even larger numbers participated in events organized to mark the same day in 2013 and 2014. All of these activities were coordinated by civil groups, as - in the end - was the unofficial vote on independence held on 9 November 2014. 
Apart from these grand-scale events, the civil contribution to pro-independence activism has also included lipdubs, flashmobs, concerts, traditional cultural events, websites, videos, books and international publicity campaigns. There is no doubt that the success and visibility of these activities are a testament to the strong feelings of many Catalans in favor of Catalonia's "right to decide".

The dynamism of these civil groups has led many Catalans to characterize the independence movement as a "bottom-up" phenomenon (as opposed, for example, to a "top-down" Scottish equivalent). ${ }^{4}$ Furthermore, it is assumed that the apparent "radicalization" of Catalonia's main nationalist party Convergència $i$ Unió (CiU, Convergence and Union) since 2012 is substantially attributable to civil pressure. ${ }^{5}$ The major partner in the CiU federation - Convergència Democràtica de Catalunya - has certainly shifted from a long-standing tendency to respond positively to territorial accommodation, to an explicitly proindependence position. Nevertheless, as Richard Gillespie reminds us in the introduction to this collection, nationalist political parties "place emphasis on changing strategic options at different times and in different contexts". ${ }^{6}$ However difficult it might appear for CiU to step off the path to independence at this point, the party's historical desire for accommodation within the Spanish state remains part of its identity, and may re-surface if circumstances change. Similarly, however useful the label "bottom-up" may appear as a shorthand way of referring to the rise of the civil independence movement in Catalonia, it may actually obscure as much as it reveals. Manuel Castells reminds us that all power networks are in fact multidimensional and reliant on "the interactive production of meaning". ${ }^{7}$ We therefore need to be alert to the complex mechanisms by which this production of meaning occurs.

The aim of this contribution is therefore to examine the place and influence of civil associations within the overall drive for Catalan independence. It begins with a brief analysis of the shifts that have taken place in the last decade, during which independence has unexpectedly come to dominate the political agenda thanks to a change in the focus of Catalan nationalism that can be attributed both to the political elites and to an ever-growing subset of Catalan civil society. In trying to unravel the networks of influence that have come to propel the Catalan polity towards a clash with the Spanish state, the discussion 
also considers the role of the cultural elites, since their ability to articulate the arguments for independence and to disseminate these through both traditional and new media has been central to the success of the civil pro-independence movement.

\section{The Shifting Dynamics of Catalan Nationalism}

Studies of nationalist movements generally stress the role of intellectual and political elites in formulating nationalist projects, for which they then recruit supporters from different parts of society. ${ }^{8}$ The study of Catalan nationalism has been no different, painting it as primarily a bourgeois phenomenon that has depended on the intellectual elites at times when Catalonia had no autonomous government of its own, and on the political elites since the re-establishment of the Catalan parliament in $1980 .{ }^{9}$ Certainly, the twenty-three year period of government by Jordi Pujol and CiU from 1980-2003 saw the consistent top-down dissemination of discourses designed to convince Catalans (and others) that Catalonia was a nation and therefore deserved special treatment. ${ }^{10}$ José María Aznar's attempt to clamp down on concessions to Catalonia during his second term as Spanish prime minister from 2000-4 therefore increased Catalans' hostility to the Spanish state, not just because of the practical effect of this attitude but also because of his attempts to promote a common Spanish national identity. ${ }^{11}$

It was in this context that discussions first began about reforming the Catalan Statute of Autonomy that had been in force since 1979.12 The process, led by the new president of the Generalitat Pasqual Maragall, was a tortuous one during which an initial consensus in the Catalan parliament disintegrated in the face of changes to the text imposed by the Spanish government. The effects of this were far-reaching, finally leading to the collapse of the three-way coalition that had kept Maragall in power. ${ }^{13}$ Not only this, but when the revised text was put forward for approval by the Catalan people in a referendum, the turnout failed to reach $50 \%$. Although there was no requirement to reach this threshold, and $73.2 \%$ of the voters were in favor, the low turnout was seen by many as an indicator of public apathy towards the Statute and a reflection of the top-down nature of the reform process. ${ }^{14}$ It was not until four years later that it became 
clear that this apathy had mutated into an unprecedented level of public engagement, as evidenced by the mass demonstration of July 2010, whose aim was specifically to protest against the changes to the Statute imposed by Spain's Constitutional Court.

This level of civil commitment would not have been possible without topdown stimuli such as the nationalizing project of Jordi Pujol and the growing sophistication of the pro-independence discourse of Esquerra Republicana de Catalunya (ERC, Republican Left of Catalonia), which had begun to concentrate its arguments for secession on citizens' welfare and life opportunities rather than the Catalan nation per se. ${ }^{15}$ However, in the last few years the mobilizing power of political leaders has apparently been eclipsed by that of the civil proindependence organizations. Is this a chiastic process by which political parties have gradually lost influence while civil organizations have gained it, or has the Catalan independence movement simply become more multidimensional?

In an article written to dispute the common perception that Spain's transition to democracy in the 1970s was almost exclusively a top-down process, Monica Threlfall examines the concept of "co-construction". She defines this as "a dynamic of change akin to a round of forceful tugs-of-war between opponents", that can be analyzed as "a narrative of transactions". ${ }^{16}$ In other words, the concept of co-construction allows for a more nuanced view of this kind of political process and directly addresses the multidimensionality of power networks highlighted by Castells. It spans both collaborative and antagonistic interactions, but also allows for the possibility of a stable outcome. ${ }^{17}$ In this sense, perhaps one of the difficulties of using it to describe the Catalan independence movement is that as yet we have no idea of what that outcome might be. In contrast, hindsight offers us the realization that the product of the political struggles in Spain in the 1970s was a stable democracy, i.e. something had indeed been "constructed". In the Catalan case, there are two main dimensions along which processes of co-construction could evolve, one mainly antagonistic - the struggle to achieve recognition of Catalonia's "right to decide" from the Spanish state - and the other potentially both collaborative and antagonistic - the attempt to create a united pro-independence movement 
spanning both political and civil groups. It is the second of these that concerns us here.

\section{Catalan Civil Society and the Pursuit of Counterpower}

Definitions of the term "civil society" vary, as do assumptions about what groupings might legitimately be described as forming part of it. ${ }^{18}$ Nevertheless, this brief definition by Michael Walzer seems to recur as one of the most useful basic conceptualizations: civil society is "the space of uncoerced human association and also the set of relational networks - formed for the sake of family, faith, interest, and ideology - that fills this space". ${ }^{19}$ It is the last in Walzer's list of motivations - ideology - that gives rise to one of the grey areas in definitions of civil society. This concerns the relationship between political associations and civil society: should collective action be defined as "civil" only when it is totally free from political partisanship? ${ }^{20}$ In the case of nationalist ideologies, both political and civil groups championing nationalist aspirations may combine this with other goals such as democratic reform, republicanism, or a return to traditionalist conservatism. Where such a spectrum exists, it can give rise to a coherent nationalist "movement" only when a clear political goal - e.g. independence - is held in common by at least a preponderance of these groups.

Even when civil groups welcome members irrespective of their partypolitical allegiances and have mainly cultural goals, they often aim to influence policy-making, for example on support for minority languages. As Michael Edwards points out, it is impossible to divorce the aims of such civil associations from "political society", and moreover "Social movements are most effective when they are anchored in a broader repertoire of contentious politics that connects them to their targets and their allies over time". ${ }^{21}$ Otherwise they are unable effectively to exercise what Manuel Castells calls "counterpower": "the capacity of social actors to challenge the power embedded in the institutions of society for the purpose of claiming representation for their own values and interests". 22

One of the factors that has traditionally united political and civil nationalist groups in Catalonia is a reluctance to pursue the idea of a Catalan state. Rather, both groups have concentrated on demands that would make it 
easier for Catalans to keep their distinctive character while still forming part of Spain. Historian Jaume Vicens Vives explained this hesitation as a consequence of the Catalans' longstanding inability to grasp state power, which has led them to dismiss it as something alien to the Catalan people. ${ }^{23}$ Paradoxically, the strong civil element in the contemporary independence movement actually raises the question of whether civil society's desire to exercise counterpower at this point in history is really an attempt to seize power in the form of a Catalan state, or fundamentally a protest against the way power is being exercised by the Spanish state.

The association between Catalan civil society and Catalan nationalism has traditionally been stressed as being crucially important whenever Catalans have been denied political power, e.g. during periods of authoritarian Spanish rule. For example, Albert Balcells states that during the Franco dictatorship, civil action was the only way of resisting "the attempt to assimilate and de-Catalanize the country" and - despite the existence of clandestine political parties - "had an existence and dynamics all of its own". ${ }^{24}$ As a result, the dynamism of Catalan civil society has become part of the myth of Catalan national identity itself, along with the two opposing features that are said to typify the Catalan character: seny (common sense) and rauxa (sudden action taken without regard for the consequences). ${ }^{25}$

Nevertheless, the rauxa that could be unproblematically associated with popular action at times when Catalonia had no political elites of its own might be awkward for the Catalan ruling parties in the new democracy, because it threatens their hold on power. This can be illustrated by a recent article published by the Centre named in honor of the former president of the Catalan Government, Jordi Pujol, in which Professor of History Andreu Mayayo is at pains to play down the significance of civil action in the democratic era. For example, he dismisses the mass demonstrations of 11 September 1977 (when participants demanded autonomy for Catalonia after the dictatorship) and 11 September 2012 (when they marched in favor of independence) as insignificant in their lasting impact compared with the elections of 15 June 1977 (in Spain) and 25 November 2012 (in Catalonia) respectively. ${ }^{26}$ In doing so, he demotes civil society to its "proper" place below institutional politics, with a stark warning 
that there is short step from civil expressions of dissatisfaction with politics to "populism and fanaticism".27 Mayayo urges Catalonia's political leaders not to give in to civil pressure for hasty action on independence, but to follow the advice of Jaume Vicens Vives, given half a century earlier, not to let their seny desert them at the time when it is most needed. ${ }^{28}$ Mayayo's comments confirm that the relationship between civil and political actors in the co-construction of a unified independence movement is as antagonistic as it is cooperative.

\section{Catalan Cultural Elites and their Communication Power}

Even if we conceptualize the relationship between the political and civil elements of the independence movement in terms of co-construction, this is still partly an oversimplification. This is because an important element in the success enjoyed by civil groups is the role played by Catalan cultural elites in their formation and direction. Referring to civil groups as the "bottom" therefore risks giving the false impression that they represent a primarily grassroots movement. As noted above, intellectuals and cultural practitioners have been a driving force in Catalanism throughout its history, even though the existence of autonomous political institutions since 1980 has meant that party-political machinations have somewhat overshadowed their role. With the recent shift in emphasis towards demands for independence rather than autonomy, the role of the cultural elites has once again become central to shaping Catalanism's major currents of thought and activity.

This group still incorporates the traditional members of the educated middle classes, such as writers and academics, who inspired the birth of Catalanism in the nineteenth century and led Catalonia's cultural resistance to the Franco regime. ${ }^{29}$ However, in its contemporary manifestation it also includes a broad spectrum of media professionals, whose influence is more far-reaching because of their access to mass as well as elite forms of communication. The presence of these cultural and media elites within the civil pro-independence movement - especially its leadership groups - therefore further problematizes any "bottom-up/top-down" distinction.

Moreover, these journalists and television and radio professionals have a sophisticated understanding of the power of social media to extend their 
personal and professional influence beyond their regular outlets. Indeed, academics and cultural practitioners are also increasingly using social media to disseminate their own thoughts to a broader public. ${ }^{30}$ This means that the contemporary Catalan independence movement as a whole has very much been built on the "communication power" offered by Web 2.0 technologies. ${ }^{31}$ This is unsurprising, given that - as Manuel Castells puts it - "social movements exercise counterpower by constructing themselves in the first place through a process of autonomous communication", which means that their task is greatly facilitated by new forms of media that allow them to occupy the communication spaces not regulated by governments and the mass media. ${ }^{32}$ Catalans are consummate "citizens of the Information Age", so it is no surprise that the civil pro-independence movement has been capable of "occupying the media and the message" within Catalonia itself, to the point that the discourse of independence is now virtually hegemonic. 33

The practical and organizational benefits of the internet and social media are also key to the movement's success. For example, in their study of "activism in the internet age", Jennifer Earl and Katrina Kimport draw a distinction between the "activist" and the "participant", and note that Web 2.0 technologies make it easy to participate in forms of protest such as email campaigns and online petitions without needing to adhere to a particular organization. ${ }^{34}$ In the same way, "participation enabled by ICT usage more generally has been found to be less driven by a personal connection with a social movement". 35 The Catalan civil pro-independence movement can therefore reach a massive pool of potential participants who feel strongly about the issues but are under no obligation to make any ongoing commitment to a particular organization. If they do choose to support a specific event, the satisfaction derived from participation, and the feeling of community engendered not only by the protest event but by the constant social media "chatter" that surrounds it, may predispose people to agree to take part in other events, whether or not they also decide to become members of a civil pro-independence organization.

Civil groups certainly recognize the importance of such "chatter" and do their very best to encourage it. For example, the march held in Barcelona on 10 July 2010 was billed by the organizers as the world's first "Demonstration 2.0", 
with a temporary Wi-Fi network created along the route to ensure that those present could upload their comments to Twitter and their photographs to Flickr, using the hashtag \#somunanacio ("we are a nation"). ${ }^{36}$ This allowed constant communication with interested parties who were not able to join the march. It would no doubt also have enhanced the feelings of active participation of the demonstrators themselves, who had a double role: not just to march, but to narrate the day's events to others. Furthermore, thanks to new communication tools, such events can now be organized by relatively small teams - or even "drastically" small ones. ${ }^{37}$ This was the case with a "Lipdub for Independence" filmed in the town of Vic in 2010 that was coordinated by a small and largely anonymous group who managed to involve 5771 participants. ${ }^{38}$

There are numerous examples of this kind of activity over the last few years, but in order to bring some focus to this discussion I will concentrate on the work of one particular association, the Assemblea Nacional Catalana (Catalan National Assembly, ANC). The case study begins with a close look at the ANC's organization of two major events, before moving on to discuss the structure of the ANC itself, and its pivotal role in the civil movement. By examining the ANC in detail we can begin to assess how the civil movement's appropriation of communication power - in all its multidimensional forms - works in practice to facilitate its attempt to exercise counterpower and shape the political agenda.

\section{The Assemblea Nacional Catalana}

The Assemblea Nacional Catalana was officially founded in March 2012 after preliminary discussions starting the previous year. Its name is deliberately modeled on that of the Assemblea de Catalunya, which functioned in the 1970s as a coordinating body for Catalanist opposition to the Franco regime. Existing cultural associations, and connections made during the organization of unofficial votes on independence across Catalonia from 2009 onwards, provided a readymade pool of potential supporters. By mid-2014 it had more than 30,000 full members and 15,000 'sympathizers' (who support its work but do not pay a membership fee). It also had 80,000 followers on Twitter and more than 100,000 'Likes' on Facebook. 
The person chosen to lead the association was Carme Forcadell i Lluís, a Catalan philologist with a background in both education and language planning. In the early 1990s, Forcadell was one of the founders of the Plataforma per la Llengua, whose aim is to promote and defend the use of the Catalan language wherever it is spoken. She is also a member of Òmnium Cultural, a Catalan cultural organization founded in the 1960s that has also organized large-scale pro-independence events (and whose conversion from a cultural association to a stalwart of the pro-independence campaign once more confirms the pivotal role of the cultural elites in the movement). Not only does Forcadell have many years of experience and strong networks on which to draw, she has also become an effective symbol for the civil movement, and one of its main voices.

The ANC's first major activity was to organize a massive demonstration in Barcelona on 11 September 2012, as a call for Catalonia's politicians to work immediately for independence. Although attendance figures are disputed, it is estimated that as many as 1.5 million Catalans joined the march. Transport alone proved a major exercise in logistics, with over a thousand buses bringing in people from outside Barcelona, and trains chartered by the municipal councils of Figueres and Girona. Mobilizing so many people through an association that had just been formed is a remarkable feat, but many of the ANC's founding members were drawn from other associations or had relevant experience in local government, the media, and business. The ANC worked closely with both political parties and other civil associations, capitalizing on their existing memberships and networks rather than needing to create an entirely new one of its own. After the march itself, a group of delegates was received at the Catalan Parliament to make a request on behalf of the demonstrators that it should start to do whatever was necessary to achieve independence for Catalonia.

One of the key pieces of evidence for characterizing Catalonia's independence movement as "bottom-up" is the unexpectedly large number of people who took part in this demonstration, and the clear message delivered to Catalonia's politicians that the participants wanted independence rather than any other compromise. It appeared, then, that a substantial number of Catalans were willing to be more radical than their political representatives, since at the time President Artur Mas was concentrating his efforts on trying to achieve more 
fiscal autonomy for Catalonia within Spain. While this is true to an extent, the coherence of the message promoted by the ANC cannot be straightforwardly taken as representative of all 1.5 million demonstrators. Even though they were clearly told that if they participated they would be counted as supporters of independence, ${ }^{39}$ there was no doubt a wide range of motivations, including the fact that the march was a good opportunity to demonstrate frustration with the ineptitude of both Spanish and Catalan politicians in handling Spain's economic crisis. Nevertheless, the demonstration appeared to galvanize Mas into action, prompting him to make the commitment to a referendum demanded by the ANC. He then called early elections for November 2012 in a - failed - attempt to rally pro-independence voters around $\mathrm{CiU}$, an action that left many wondering whether his commitment to a referendum was just a matter of political expediency.

In fact, the events of September to November 2012 can be better explained as an example of co-construction, since they illustrate the complex and reciprocal relationship between civil movements and institutional action in fostering a pro-independence consensus. As Mayayo points out, Mas was perhaps overly influenced by the mass support for the demonstration, ${ }^{40}$ but even if this was because he saw an opportunity to increase his personal influence and the power of $\mathrm{CiU}$, the ANC nevertheless had achieved a significant shift in the political landscape. The second half of 2012, during which support for independence rose further than at any other time since comparable records began in $2005,{ }^{41}$ is perhaps the point at which we can start to talk of a genuine secession crisis in Catalonia.

The organization of the "Catalan Way" (Via Catalana) for 11 September 2013 was even more complex than the demonstration of the previous year, since the idea was to form an unbroken human chain from the French border in the north to Valencia in the south. This would require a minimum of 400,000 participants, divided between nearly 800 sections of the route. Participation was coordinated via a website, where people were asked to sign up to a particular section. Filling the southern sections proved particularly problematic because of the lower population of the area, and so a plea went out to people from other parts of Catalonia to travel south. The pro-independence newspaper ARA put its 
own influence behind this call, even offering a month's free digital subscription to those who signed up. More than 100,000 photographs were taken along the route to provide a "Gigafoto", allowing people to search later for their own photograph on the ANC's website. Ultralights were used to film the route from the air, with the results quickly being made available on YouTube. Media coverage was closely coordinated by the ANC, with chosen journalists being given advance information not available to the public so that they would be in the right place to cover key "surprise" events on the day. ${ }^{42}$ In the event, the Catalan Way saw an estimated 1.6 million people take part in the human chain and its associated activities. $\underline{43}$

It will be clear from this description that the Catalan Way was a massive feat of coordination, organization and motivation. In 2014, Anna Rosenfeld and Joan Serra published a book that narrated the process of designing and coordinating the Via Catalana from start to finish, and here we can find many of the answers to how such a feat was possible. ${ }^{44}$ Firstly, the idea of the Catalan Way did not come suddenly out of the blue but had been in various people's thoughts for some time: in fact a Facebook page already existed to try to drum up support for such an event, and was taken over as the ANC's official Via Catalana page. ${ }^{45}$ Secondly, the main organizers were people with an extensive network of connections, including - coincidentally - with people who had participated in the Baltic Way of 1989 (linking Lithuania, Latvia and Estonia) on which the Catalan event was modeled. ${ }^{46}$ Existing relationships with filmmakers, graphic designers and IT experts were crucial in promoting the event, and many of these people gave their time for free. As well as using Facebook and the ANC's webpages, the organizers kept in touch via WhatsApp, which allowed the six regional coordinators to be in constant contact with the main team based in Barcelona. ${ }^{47}$

Decentralization was one of the main features of the organizational structure, in which a total of five thousand ANC members and other volunteers were distributed in a pyramid that had at its base one section coordinator for every five hundred meters of the human chain itself. This mirrored - and took advantage of - the ANC's own decentralized structure, which includes both territorial and sectorial assemblies. In the case of the sectorial assemblies, many of these are grouped by profession (including firefighters, teachers and IT 
workers), but they also cluster around other forms of commonality, such as a gay and lesbian group and a women's group. As far as finding participants for the event was concerned, Rosenfeld and Serra sum up the ANC's approach as "taking advantage of '2.0' networks to spread the word that the chain needed to be filled, but using '1.0' personal contact to fill it”. ${ }^{48}$ In other words, the encouragement of friends, neighbors and family members would be crucial in ensuring that the ANC's messages were not only received but also translated into action.

The culmination of the day's events was a speech given by the ANC's president, Carme Forcadell, surrounded by thousands of people in Barcelona's Plaça Catalunya. In order that they would feel part of this moment, people along the route had been encouraged to bring radios to listen to her speech (and discouraged from trying to use their mobile phones to hear it, as this would collapse the phone networks). ${ }^{49}$ Forcadell, looking tired and serious, called for Catalonia's politicians to hold a referendum on independence without delay, saying that independence was the only way of guaranteeing Catalonia's future as a distinct nation. There was no triumphalism in her speech, which concentrated on laying out the reasons for the day's action and the task that lay ahead. This earnestness, combined with her obvious emotion once the speech was over, might be seen as emblematic of the difference the ANC needs to project between civil and party-political approaches to independence: the civil movement appears to be expressing a heartfelt collective desire without self-interest or the potential for hypocrisy.

The fact that the ANC is led by a woman, as is Òmnium Cultural, provides an interesting contrast with the male-dominated leadership of the proindependence political parties. Indeed, the satirical television series Polònia (TV3), in which actors impersonate key political and cultural figures, has taken advantage of this to create a group of recurring characters called 'Les Catalines' ('The Catherines'). The trio consists of Forcadell, Muriel Casals from Òmnium Cultural, and one man in drag: Josep Maria Vila d'Abadal, president of the Associació de Municipis per la Independència, an umbrella group for proindependence local councils. The three are depicted as obsessed with cooking and cleaning, they wear "frumpy housewife" clothes, and they share an apartment. This format is based on the comedy series Teresina S.A. (TV3, 1992), 
in which a group of three resourceful sisters use their apartment as the premises for a business making up props for traditional festivals. The comparison suggests that the civil independence movement itself is a kind of "cottage industry" when compared with the resources enjoyed by the political parties.

One particularly interesting sketch from March 2014 portrays Forcadell as the "mistress" of Catalan president Artur Mas. Forcadell calls Mas from her bedroom to propose a series of improbable forms of celebration on the day Catalonia declares independence. She is depicted lying on a bedspread made of an Estelada - the pro-independence version of the official Catalan flag. Mas eventually cuts off her list of ever more impossible suggestions, telling her he needs some space and they should "take a break". Forcadell asks if he is leaving her for "Òmnium Cultural" (Muriel Casals), but Mas insists he simply needs to be able to proceed without her interfering. Before slamming down the phone, Forcadell reminds him that nobody can organize human chains for him like she does. The gender-stereotyping that underpins the sketch (and "Les Catalines" as whole), neatly illustrates the uncomfortable relationship between political and civil action, and the stark reality of the dominance of institutional power over civil counterpower. Civil action is welcome only when it serves the goals of the political elites.

Nevertheless, the ANC is well aware of the advantages it has in the current situation, and it is able to exploit these to the full. The Assemblea has an agility and a capacity for flexibility that political parties and institutions do not enjoy. Networks can therefore be used to achieve much faster results, aided by the instant communication and organizational efficiency afforded by forms of "emobilization". ${ }^{50}$ Its decentralized structure allows for simultaneous actions at a variety of scales and ensures that all members feel central to its efforts. This in turn affords both members and occasional volunteers a sense of agency that is perceived no longer to be available through the normal channels of institutional democracy. ${ }^{51}$ The immediacy of local contact combined with impressive mass mobilization also helps to convince people that support for independence is now the default position, i.e. the "tipping point" beyond which support for secession is a safe preference has been surpassed..$^{52}$ 
The ANC's success might be summarized by saying that it has managed to reduce the costs involved in active participation in the civil pro-independence movement, while increasing the benefits. In terms of costs, participants obviously give up their time, and there are likely to be monetary costs too. By organizing transport, keeping people entertained, and financing events through the sale of merchandise that gives people something by which to remember their contribution, the ANC both reduces these costs and makes participation as pleasurable an experience as possible. ${ }^{53}$ Moreover, all the publicity for the Catalan Way stressed that this was a historic event, implying that anyone not taking part would later regret this. ${ }^{4}$ The idea of a "Gigafoto" reinforced this by promising to "immortalize" the presence of each individual. ${ }^{55}$ Taken together, these kinds of actions stimulate vital affective responses: a sense of belonging to the community, a deep emotional connection with fellow participants, enjoyment - however brief - of a form of political agency denied by political institutions, and pride in being useful to a national community that is perceived to be under threat.

Nevertheless there are some contradictions in the ANC's role in Catalonia's secession crisis that might eventually prove problematic. One of these is the disjunction between its decentralized structure and the increasing importance of Carme Forcadell as a key figure not just for the ANC but for the independence movement as a whole. Historically, one of the major problems of Catalan separatism (and Catalan nationalism more generally) has been its fragmentation into disparate groups that have failed to bury their differences long enough to achieve game-changing results. ${ }^{56}$ These groups may represent different positions on the left-right spectrum, or different understandings of exactly what is meant by "independence" and the best way to achieve it. Since support for independence began to grow in the middle of the last decade, there has been a - sometimes desperate - search for individuals who might succeed in uniting these disparate parts. For example, Josep-Lluís Carod-Rovira, the former leader of ERC, was unable to do this despite being very influential in normalizing the idea of independence itself. As we saw above, Artur Mas may have now become the secession movement's best hope for institutional action, but his sudden conversion to the cause leaves many wondering whether he will stand 
firm in the face of increased threats and/or potential offers of compromise from Madrid. In 2009-10, it was the former president of FC Barcelona Joan Laporta who looked like he might finally break through as a figurehead for the independence movement as a whole, but after forming and then leaving his own party (Solidaritat Catalana per la Independència), he has faded from view. Forcadell's success since becoming president of the ANC in 2012 is therefore significant, and as I have suggested above, this can partly be attributed to the impression she gives of a genuine commitment to the collective good rather than to personal power. However, there is a significant risk that when she steps down as president in mid-2015 the pro-independence movement as a whole might suffer a loss of momentum.

Indeed, the fragmentation of the secessionist cause might be said to have benefits as well as disadvantages, especially given that social media and other Web 2.0 technologies can now mitigate some of the worst effects of this fragmentation. As Baldassarri and Diani have shown, hierarchically-organized civic networks are actually quite vulnerable, since "if we remove from the network the core actors, whose commitment secures network cohesiveness, the entire network collapses". ${ }^{57}$ Moreover, "hierarchical structures are based on relations of asymmetric interdependence that are not likely to induce horizontal solidarity and generalized exchange". ${ }^{58}$ "Polycentric" networks, on the other hand, are more stable because power is shared and this inequality is therefore avoided. ${ }^{59}$ However, Baldassarri and Diani also argue that polycentric networks are less suited to the organization of mass events. A balance therefore needs to be struck between the stability offered by polycentrism and the efficiency of a top-down approach.

As we have seen, the ANC attempts to strike this balance in its internal organization, but this is also becoming a central feature of the civil proindependence movement as a whole. As already noted, links between different organizations are relatively easy to cultivate because of well-established personal relationships and the clarity of the shared overall goal (a referendum on independence). Typically, many different associations will collaborate on a large event, and this works well when tasks can be separated and allocated to particular groups. However, Rosenfeld and Serra highlight the fact that an 
attempt by Òmnium and the ANC to jointly coordinate two big events - the Catalan Way and a "Concert for Freedom" - had to be abandoned because it hindered swift and efficient decision-making. 60 The requirement for each organization to carry out appropriate internal consultation, and the differences in their internal structures, made co-organization of the events impractical. ${ }^{61} \mathrm{On}$ the other hand, once it was decided that Òmnium would take the lead on the concert and the ANC the Via Catalana, each group could collaborate effectively in particular areas of the event the other was organizing. In other words, one association had to allow itself to become temporarily subordinate to the other in order to ensure enough "hierarchical" organizational power to make the event a success.

\section{Conclusion}

A close look at the ANC reveals both its inner multidimensionality and its place within an independence movement that is of course itself multidimensional. Although at the time of writing it is too early to tell whether the movement will achieve its aim of independence for Catalonia, it does appear that civil groups have been able to exercise significant influence in the "tugs-of-war" that surround this goal. ${ }^{62}$ Clever use of the communication power afforded by new technologies appears to be crucial to this success, although much more research is needed in order to understand the mechanisms that underpin this. What we can say for certain is that the character of Catalan nationalism has undergone a significant shift since the middle of the last decade, away from the mass political apathy that characterized that particular period (as demonstrated by the low turnout in the 2006 referendum on Catalonia's new Statute of Autonomy), and towards mass participation in civil action for independence. It is also clear that the counterpower of the civil movement has had some measureable effects: political parties are being made to shift their positions to accommodate (at least to some extent) the civil movement's desire for swift and decisive action on independence.

Nevertheless, Catalan political institutions still have absolute control of the mechanisms by which this desire might be translated into some kind of reality. Scott Greer argued in 2007 that "secession seems unlikely" in the Catalan 
case because the regional political elites have too much to lose by such a move and are most concerned with winning further autonomy in specific areas that stabilize their own hold on regional power. ${ }^{63}$ While secession now appears to be a much more credible possibility than ever before because of the blocks that have been put on territorial accommodation by the Spanish government, Greer's basic point still holds true: Catalonia's political elites are unlikely to do anything that would jeopardize their own position.

Furthermore, as has been argued here, any analysis of the movement in terms of "bottom-up" versus "top-down" dynamics ignores the crucial role of the cultural elites. It has been the conversion of the Catalan middle classes to support for independence rather than "pragmatic Catalanism" that has turned what was hitherto a minor component of Catalan nationalism into a mass secession movement. ${ }^{64}$ In common with the pattern of Catalan nationalism throughout most of its history, then, the current constitution of mainstream forms of Catalanism places the cultural and intellectual elites at the heart of the movement. The cultural elites - especially those with experience in sectors related to the media - also play a crucial liaison role between the political elites and the civil associations. Partly thanks to the cultural elites' position at the intersection of these two groups, networks of influence radiate both vertically and horizontally from the civil organizations and political parties that make up the core of the independence movement, reaching out towards potential supporters in all areas of Catalan society.

It is too soon to judge who will end up having the decisive role in whatever situation eventually results from the resolution of this secession crisis. Naturally, the outcome relies on another "tug-of-war" - the battle between the Catalan independence movement and the Spanish state - that might actually result in either the triumph of the status quo or a "third way" involving greater devolution. Even if independence did become a reality, the civil values and antistate rhetoric espoused as part of the campaign could come back to haunt the leaders of the new Catalonia. As Clifford Geertz said in relation to postcolonial nations, once a new era of independence is entered, "it is necessary now to live in it rather than merely imagine it, and that is inevitably a deflating experience". 65 Whatever the end result, it is clear that the new situation will have been co- 
constructed by political and civil forces that both have elite as well as more grassroots elements, and idealized notions that the process represents a triumph of civil society over political institutions should therefore be avoided.

\footnotetext{
${ }^{1}$ Viva Ona Bartkus, The Dynamic of Secession (Cambridge: Cambridge University Press, 1999), 10.

${ }^{2}$ For an account of the rise in support for independence in Catalonia see Kathryn Crameri, "Goodbye, Spain?" The Question of Independence for Catalonia (Brighton: Sussex Academic Press/Cañada Blanch, 2014), and Andrew Dowling "Accounting for the Turn Towards Secession in Catalonia," International Journal of Iberian Studies 27(2-3): 219-234 (2014).

3 Stephen Burgen, "Catalan Independence Rally Brings Barcelona to a Standstill", The Guardian, 11 September 2012. http://www.theguardian.com/world/2012/sep/11/catalan-independencerally-barcelona (accessed 14 December 2014).

${ }^{4}$ Montserrat Guibernau, "Prospects for an Independent Catalonia," International Journal of Politics, Culture, and Society 27(1): 5-23 (2014): 5; Vicent Partal, "No som Escòcia," Vilaweb, 22 February 2013,
} http://www.vilaweb.cat/editorial/4087469/som-escocia.html (accessed 4 April 2014).

${ }^{5}$ Guibernau, "Prospects for an Independent Catalonia"; Enric Ordeix and Xavier Ginesta, "Political Engagement Principles as the Basis for New Regional SelfDetermination Processes in Europe: The Case of Catalonia," American Behavioural Scientist 58(7): 928-40 (2014): 930.

${ }^{6}$ Richard Gillespie, this collection, $\mathrm{p}$.

7 Manuel Castells, Communication Power (Oxford: Oxford University Press, 2009), 132.

${ }^{8}$ Montserrat Guibernau, Nations without States: Political Communities in a Global Age (Cambridge: Polity, 1999), 90-94.

${ }_{9}^{9}$ Albert Balcells, Catalan Nationalism: Past and Present, trans. Jacqueline Hall (London: Macmillan, 1996), 23; Thomas Jeffrey Miley, "Against the Thesis of the 'Civic Nation': The Case of Catalonia in Contemporary Spain," Nationalism and Ethnic Politics 13(1): 1-37 (2007).

10 The extent to which these were successful can be briefly exemplified by the fact that in 1996, a survey cited 34\% of respondents as describing Catalonia as a nation while a similar question put the percentage at 51\% in 2005 (Kenneth McRoberts, Catalonia: Nation Building without a State (Don Mills, Ont. New York: Oxford University Press, 2001), 164, 168; El Periódico, 9 October 2005, 2, survey conducted by GESOP).

11 Guibernau, "Prospects for an Independent Catalonia," 15; Sebastian Balfour and Alejandro Quiroga, The Reinvention of Spain: Nation and Identity since Democracy (Oxford: Oxford University Press, 2007), 109-10.

${ }^{12}$ Enric Martínez-Herrera and Thomas Jeffrey Miley, "The Constitution and the Politics of National Identity in Spain," Nations and Nationalism 16(1): 6-30 (2010): 25.

${ }^{13}$ Andreu Orte and Alex Wilson, "Multi-level Coalitions and Statute Reform in Spain," Regional \& Federal Studies 19(3): 415-36 (2009): 424-30. 
${ }^{14}$ Martínez-Herrera and Miley, "The Constitution," 27. See also Crameri, “Goodbye, Spain?", 40.

15 Josep-Lluís Carod-Rovira, 2014 (Barcelona: Mina, 2008).

16 Monica Threlfall, "Reassessing the Role of Civil Society Organizations in the Transition to Democracy in Spain," Democratization 15(5): 930-51 (2008): 931. 17 Ibid., 932.

18 Michael Edwards, Civil Society, 2nd ed. (Cambridge: Polity, 2009), 4.

19 Michael Walzer, "The Idea of Civil Society: A Path to Social Reconstruction," in Community Works: The Revival of Civil Society in America, ed. E. J. Dionne Jr. (Washington, D.C.: The Brookings Institution, 1998), 124.

20 Edwards, Civil Society: 25-28.

21 Ibid., 32.

22 Manuel Castells, Networks of Outrage and Hope: Social Movements in the Internet Age, (Cambridge: Polity, 2012), Kindle location 196.

23 Jaume Vicens Vives, "The Catalans and the Minotaur," in Catalonia: A Self Portrait, ed. Josep Miquel Sobrer (Bloomington, IN: Indiana University Press, 1992), 97-98, 105.

24 Balcells, Catalan Nationalism: 145.

25 Enric Ucelay Da Cal, "Més que un club? Exploració d'un relat persistent," Metropolis: Revista d'informació i pensament urbans 71: 47-57 (2008). ${ }^{26}$ Albert Mayayo, "L'error metonímic, l'error metafòric," VIA22 10: 41-52 (2013): 44-45.

27 Ibid., 47.

28 Ibid., 51-2.

29 Joan-Lluís Marfany, La cultura del catalanisme (Barcelona: Empúries, 1995);

Salvador Giner, The Social Structure of Catalonia, Anglo-Catalan Society

Occasional Publications (The Anglo-Catalan Society, 1984), 57-59.

30 Xavier Lasauca i Cisa to UK Web Focus, 2012, http://ukwebfocus.wordpress.com/2012/11/05/social-media-analytics-for-rda-catalan-vision/ (accessed 5 November 2014).

31 The term 'Web 2.0' refers to forms of digital communication that allow twoway communication and collaboration, compared to earlier, more static, forms such as informational websites.

32 Castells, Networks of Outrage: 9.

33 Ibid.

34 Jennifer Earl and Katrina Kimport, Digitally Enabled Social Change: Activism in the Internet Age (Cambridge, MA: MIT Press, 2011), 92-3.

35 Ibid., 28.

36 Òmnium Cultural, "La manifestació del 10 de juliol serà la primera marxa 2.0," http://www.somunanacio.cat/ca/noticia/la-manifestacio-del-10-de-juliol-serala-primera-marxa-2-0-4285.html (accessed 19 August 2013).

37 Earl and Kimport, Digitally Enabled Social Change: 163.

38 Oriol Freixenet Guitart, "Dels Cors Clavé als 'lipdub'," (2010), http://www.omnium.cat/ca/article/cultura-dels-cors-clave-als-lipdub4001.html (accessed 15 August 2013).

39 VilaWeb, "La manifestació amb més autocars de la història," VilaWeb 5 September (2012), 
http://www.vilaweb.cat/noticia/4038121/20120905/manifestacio-autocarshistoria.html (accessed 26 August 2013).

40 Mayayo, "L'error metonímic," 44-45.

41 Ivan Serrano, De la nació a l'estat (Barcelona: Angle Editorial, 2013), 125-41.

42 Anna Rosenfeld and Joan Serra, 17:14 L'hora del poble: Com vam fer la Via

Catalana (Badalona: Ara Llibres, 2014), Kindle loc. 1804.

43 ARA Barcelona, "Demonstrating the Catalan Way", ARA, 12 September 2013, http://www.ara.cat/viacatalana/catalan-way-catalonia-barcelona-

independence 0 991101153.html (accessed 14 December 2014).

44 Ibid.

45 Ibid., Kindle loc. 483.

46 Ibid., Kindle loc. 516, 549.

47 Ibid., Kindle loc. 807.

48 “'-aprofitar les xarxes '2.0' per esbombar que cal omplir la cadena, però utilitzar

el contacte personal '1.0' per omplir-la”-'. Ibid., Kindle loc. 625.

49 Ibid., Kindle loc. 1825.

50 Earl and Kimport, Digitally Enabled Social Change: 5.

51 Peter Dahlgren, "Civic Identity and Net Activism: The Frame of Radical

Democracy," in Radical Democracy and the Internet: Interrogating Theory and

Practice, ed. Lincoln Dahlberg and Eugenia Siapera (Basingstoke: Palgrave

Macmillan, 2007), 56.

52 Henry E. Hale, The Foundations of Ethnic Politics (Cambridge: Cambridge

University Press, 2008), 26-27; David D. Laitin, Nations, States and Violence

(Oxford: Oxford University Press, 2007), 58.

53 Rosenfeld and Serra, 17:14: Kindle loc. 1976.

54 Ibid., Kindle loc. 942.

55 Ibid., Kindle loc. 392.

56 Fermí Rubiralta i Casas, Una història de l'independentisme polític català: De

Francesc Macià a Josep Lluís Carod-Rovira (Lleida: Pagès Editors, 2004).

57 Delia Baldassarri and Mario Diani, "The Integrative Power of Civic Networks,"

American Journal of Sociology 113(3): 735-80 (2007), 741.

58 Ibid., 742.

59 Ibid., 741.

60 Rosenfeld and Serra, 17:14: Kindle loc. 927.

61 Ibid., Kindle loc. 919.

62 Threlfall, "Reassessing," 931.

${ }^{63}$ Scott Greer, Nationalism and Self-Government (New York: State University of

New York Press, 2007), 183.

64 Dowling, "Accounting for the Turn," 229.

65 Clifford Geertz, The Interpretation of Cultures (London: Fontana, 1993), 235. 